\title{
EFFECT OF EXCLUSIVE BREASTFEEDING ON GROWTH AND DEVELOPMENT OF INFANTS AGED O-24 MONTHS
}

\author{
Siska Nurul Abidah, Hinda Novianti \\ Faculty of Nursing and Midwifery, \\ Universitas Nahdlatul Ulama Surabaya
}

\begin{abstract}
Background: Impaired growth and development of children impact the child's future. Exclusive breastfeeding is essential for the optimal growth and development of children. This study aimed to determine the effect of exclusive breastfeeding on the growth and development of infants aged o-24 months.

Subjects and Method: This was a cross-sectional study conducted at Wonokromo district, Surabaya, East Java, from June to July 2020. A total of 40 under-two-years children was selected by purposive sampling. The dependent variable was the growth and development of children. The data for the growth of children were collected by accessing weight-for-age, length/ height-for-age, and head circumference measurement. The data for the development of children were collected using Revised Prescreening Developmental questionnaires (R-PDQ). The independent variable was exclusive breastfeeding. The data were analyzed by chi-square.

Results: Children receiving exclusive breastfeeding (96.8\%) showed a better status of growth and development than without receiving exclusive breastfeeding (11.1\%), and it was statistically significant $(\mathrm{p}<0.001)$.

Conclusion: Children receiving exclusive breastfeeding (96.8\%) show a better status of growth and development than without receiving exclusive breastfeeding.
\end{abstract}

Keywords: exclusive breastfeeding, growth and development, children

\section{Correspondence:}

Siska Nurul Abidah. Faculty of Nursing and Midwifery, Universitas Nahdlatul Ulama Surabaya. Jl. Raya Jemursari No.57, Jemur Wonosari, Wonocolo, Surabaya, East Java, 60237. Email: Siskanurul@unusa.ac.id. Mobile: +6282232261545.

The $7^{\text {th }}$ International Conference on Public Health

Solo, Indonesia, November 18-19, $2020 \mid 240$ https://doi.org/10.26911/the7thicph.03.60 